\title{
Bioedusiana
}

http://jurnal.unsil.ac.id/index.php/bioed

DOI: https://doi.org/10.37058/bioed.v6i1.2925

Bioedusiana

\section{Persepsi Mahasiswa Pendidikan Biologi terhadap Perkuliahan Daring pada Masa Pandemi Covid-19}

\section{Perception of Biology Education Students towards Online Lectures during the Covid-19 Pandemic}

\author{
Nurlia ${ }^{1 *}$, Sulasmi Anggo ${ }^{2}$ \\ 1,2 Universitas Muhammadiyah Luwuk Banggai, Jl. KH. Ahmad Dahlan No.79, Luwuk, 94711
}

\begin{abstract}
Abstrak
Perkuliahan secara daring dianggap menjadi solusi terbaik di tengah pandemi Covid-19. Berbagai kendala yang dialami selama proses perkuliahan daring serta harapan yang tidak sesuai dengan kenyataan akan menimbulkan banyak persepsi dari mahasiswa. Tujuan penelitian ini adalah untuk mengetahui persepsi mahasiswa Program Studi Pendidikan Biologi terhadap perkuliahan daring pada masa pandemi Covid-19. Penelitian ini menggunakan pendekatan deskriptif kuantitatif. Populasi penelitian ini adalah seluruh mahasiswa Program Studi Pendidikan Biologi. Teknik pengambilan sampel menggunakan purposive sampling yaitu mahasiswa yang aktif mengikuti perkuliahan daring selama 2 semester sehingga diperoleh sebanyak 49 mahasiswa. Data penelitian diperoleh dengan menggunakan angket yang diisi oleh mahasiswa melalui Google Formulir terdiri atas 10 pernyataan. Data yang diperoleh dianalisis untuk memperoleh nilai frekuensi dan persentase kecenderungan persepsi mahasiswa terhadap perkuliahan daring. Hasil penelitian menunjukkan bahwa hanya 44,9\% mahasiswa setuju perkuliahan daring dapat diakses secara mudah, $61,2 \%$ setuju perkuliahan daring tepat waktu dan sesuai dengan jadwal, $69,4 \%$ setuju bahwa materi yang disajikan secara daring sesuai dengan kontrak perkuliahan/RPS, 42,9\% tidak setuju jika perkuliahan secara daring menambah pemahaman teori dan keterampilan, 77,5\% setuju mendapatkan kemudahan dalam mengirim tugas dalam perkuliahan daring, 94\% setuju bahwa Dosen memberikan kesempatan untuk bertanya dan berdiskusi, 98\% setuju bahwa Dosen memberikan respon terhadap pertanyaan yang muncul selama perkuliahan secara daring, 98\% setuju Dosen selalu menemani ketika pembelajaran secara daring hingga selesai, 91,9\% setuju dosen menjelaskan arah dan tujuan dalam setiap pembelajaran secara daring, dan $55,1 \%$ tidak setuju jika perkuliahan daring memberi kemudahan dalam berinteraksi dengan mahasiswa lain.
\end{abstract}

Kata kunci: Persepsi; Perkuliahan Online; Covid-19

\section{Abstract}

Online lectures are the best solution in the Covid-19 Pandemic era, but on the implementation. Various obstacle experienced during online lecturing process and the expectations do not match with the reality, it will raise many perceptions from students. The purpose of this study was to determine perception of Biology Education Study Program Students towards online lectures during the Covid-19 Pandemic. This study used descriptive qualitative approach. The population of this study was all the students of Biology Education Study Program. The technique of collecting sampling used purposive sampling, namely the students that active followed online lecture during 2 semesters to obtain as many as 49 students. To collect the data, the researcher used a questionnaire filled out by the students through Google Form consisted of 10 statements. The data gained were analyzed to have the frequency value and percentage of students' perception toward online lectures. The results showed that only $44.9 \%$ of students agreed that online lectures could be accessed easily, $61.2 \%$ agreed that online lectures were on time and on schedule, $69.4 \%$ agreed that the material presented online was in accordance with the lectures contract/RPS, $42.9 \%$ disagree if online lectures increase understanding of theory and skills, $77.5 \%$ agree to find it easier to send assignments in online lectures, 94\% agree that the lecturers provided opportunities to ask questions and discuss, 98\% agree that the lecturers respond with questions that given during lectures online, 98\% agree that the lecturers always accompany online learning completed, $91.9 \%$ agree that the lecturers explain the direction and goals in each online learning, and $55.1 \%$ disagree if online lectures provide convenience in interact with other students.

Keywords: Perception; Online Lectures; Covid-19

Article History

Received: April 12 ${ }^{\text {th }}, 2021 ;$ Accepted: June 18 ${ }^{\text {th }}, 2021$; Published: June $30^{\text {th }}, 2021$

Corresponding Author*

Nurlia, P.Biologi Universitas Muhammadiyah Luwuk Banggai, E-mail: nurlia2811@gmail.com 


\section{PENDAHULUAN}

Penyebaran virus Corona (Covid-19) yang terjadi saat ini, menimbulkan dampak tersendiri bagi penyelenggaraan pendidikan di Indonesia. Penyebaran Covid-19 yang sangat cepat tentunya menimbulkan kekhawatiran baik bagi Pemerintah, orang tua maupun mahasiswa. Hal inilah yang menyebabkan sejumlah perguruan tinggi menghentikan kegiatan belajar mengajar secara tatap muka dan melaksanakan pembelajaran secara daring termasuk di Universitas Muhammadiyah Luwuk Banggai. Perkuliahan secara daring dianggap menjadi solusi terbaik terhadap kegiatan perkuliahan di tengah pandemi Covid-19. Hal ini dilakukan untuk mencegah meluasnya penyebaran dan penularan Covid-19 kepada mahasiswa. Menurut Saifuddin (2017), perkuliahan daring merupakan salah satu bentuk pemanfaatan internet yang dapat meningkatkan peran mahasiswa dalam proses pembelajaran.

Pembelajaran daring pada pelaksanaannya membutuhkan dukungan perangkatperangkat mobile seperti telepon pintar, tablet dan laptop yang dapat digunakan untuk mengakses informasi dimana saja dan kapan saja (Gikas \& Grant, 2013). Saat ini banyak platform yang bisa digunakan sebagai sarana perkuliahan daring, namun yang paling sering digunakan adalah Whatsapp Grup, Google Classroom, Zoom Meeting dan E-mail. Umumnya mahasiswa beranggapan bahwa aplikasi tersebut mudah dalam pengoperasiannya dan hemat kuota sehingga efektif dalam menunjang perkuliahan daring. Meskipun tersedia berbagai jenis aplikasi yang bisa digunakan dalam perkuliahan, namun dalam pelaksanaannya tidak menutup kemungkinan terdapat kendala. Kendala yang biasanya ditemui seperti minimnya jaringan, ketersediaan perangkat dan mahalnya paket data. Selain itu, pemberian subsidi kuota belajar dari Kemendikbud juga belum merata kepada semua mahasiswa. Menurut Pangondian et al., (2019), salah satu faktor yang mempengaruhi kesuksesan pembelajaran daring adalah dukungan ketersediaan jaringan yang merata di setiap daerah.

Adanya berbagai kendala yang dihadapi mahasiswa membuat mereka merasa kesulitan dalam mengikuti perkuliahan daring. Hal tersebut tentunya menimbulkan persepsi yang berbedabeda oleh tiap mahasiswa. Menurut Sugihartono et al., (2007), persepsi manusia merupakan hasil dari perbedaan sudut pandang dalam penginderaan. Ada yang mempersepsikan sesuatu itu baik atau persepsi yang positif maupun persepsi negatif. Setiap individu akan memiliki sudut pandang atau persepsi yang berbeda walaupun berada pada kondisi pembelajaran yang sama dikarenakan stimulan yang diterima mungkin berbeda dan diinterpretasikan dengan cara yang berbeda. Oleh karena itu, dosen perlu memiliki keterampilan mengenai cara mengajar efektif, kreatifitas, dan memotivasi mahasiswa selama perkuliahan daring berlangsung. Menurut Suyanto \& Jihad (2013), kemampuan dosen dalam melaksanakan perannya sebagai fasilitator adalah menyediakan kemudahan-kemudahan bagi mahasiswa dalam proses belajar mengajar, 
membimbing peserta didik yang mengalami kesulitan selama proses belajar mengajar, dan memberikan contoh yang baik kepada mahasiswa.

Penelitian sebelumnya terkait dengan perkuliahan daring, telah dilakukan oleh Maulah et al., (2020), mengenai persepsi mahasiswa biologi terhadap perkuliahan daring sebagai sarana pembelajaran selama pandemi covid-19 menunjukkan bahwa efektifitas pembelajaran dirasa kurang puas karena bergantung pada kemampuan dan motivasi belajar. Namun dengan menggunakan model pembelajaran seperti pemilihan media pembelajaran, model komunikasi dan gaya belajar yang tepat mengarahkan pada kesuksesan pembelajaran daring. Penelitian lainnya oleh Saragih et al., (2020) mengenai persepsi mahasiswa terhadap pembelajaran daring selama pandemi covid-19 menunjukkan bahwa mayoritas mahasiswa memiliki persepsi positif terkait pelaksanaan perkuliahan daring dalam dua aspek yaitu aspek proses belajar mengajar dan aspek kapabilitas dosen, namun memiliki persepsi negatif dalam aspek sarana dan prasarana. Keterbatasan jaringan internet dan perangkat belajar yang dimiliki oleh mahasiswa menjadi kendala bagi mahasiswa dalam mengikuti perkuliahan daring.

Berbagai kendala yang dialami selama proses perkuliahan daring serta harapan yang tidak sesuai dengan kenyataan akan menimbulkan banyak persepsi dari mahasiswa. Oleh karena itu, penelitian ini dilaksanakan dengan tujuan untuk mengetahui kecenderungan persepsi mahasiswa Program Studi Pendidikan Biologi terhadap perkuliahan daring pada masa pandemi Covid-19. Hasil yang diperoleh bisa menjadi bahan evaluasi baik bagi dosen maupun mahasiswa untuk perbaikan pelaksanaan proses perkuliahan selanjutnya.

\section{METODE}

Penelitian ini menggunakan pendekatan deskriptif kuantitatif untuk mengkaji presepsi mahasiswa mengenai perkuliahan daring. Populasi pada penelitian ini adalah seluruh mahasiswa Program Studi Pendidikan Biologi Universitas Muhammadiyah Luwuk Banggai yang aktif mengikuti perkuliahan daring. Teknik pengambilan sampel menggunakan purposive sampling yaitu mahasiswa semester II, IV, VI yang telah aktif mengikuti perkuliahan daring selama 2 semester sehingga diperoleh sebanyak 49 mahasiswa. Data penelitian diperoleh dengan menggunakan angket yang diisi secara daring oleh mahasiswa melalui Google Form yang terdiri atas 10 pernyataan dengan indikator yaitu proses belajar mengajar dan kapabilitas (kompetensi dosen). Angket yang digunakan dalam penelitian ini menggunakan skala Likert yang terdiri atas 5 pilihan jawaban. Pengumpulan data dilakukan dengan menyebar angket kepada mahasiswa, kemudian data yang diperoleh dari angket tersebut dianalisis untuk memperoleh nilai frekuensi dan persentase jawaban mahasiswa kemudian disajikan dalam bentuk grafik untuk mengetahui kecenderungan persepsi mahasiswa terhadap perkuliahan daring. 


\section{HASIL DAN PEMBAHASAN}

\section{Hasil}

Persepsi mahasiswa Pendidikan Biologi Universitas Muhammadiyah Luwuk Banggai terhadap perkuliahan daring pada masa pandemi Covid-19 berdasarkan hasil penyebaran angket melalui Google formulir, dapat dilihat pada Tabel 1. berikut.

Tabel 1. Frekuensi Persepsi Mahasiswa Pendidikan Biologi terhadap Perkuliahan Daring pada Masa Pandemi Covid-19

\begin{tabular}{|c|c|c|c|c|c|c|}
\hline \multirow{2}{*}{ No. } & \multirow{2}{*}{ Pernyataan } & \multicolumn{5}{|c|}{ Penilaian } \\
\hline & & STS & TS & $\mathbf{R R}$ & $\mathbf{S}$ & SS \\
\hline 1. & Perkuliahan Daring dapat diakses secara mudah & 0 & 13 & 14 & 22 & 0 \\
\hline 2. & $\begin{array}{l}\text { Perkuliahan Daring tepat waktu dan sesuai dengan } \\
\text { jadwal }\end{array}$ & 0 & 13 & 6 & 20 & 10 \\
\hline 3. & $\begin{array}{l}\text { Materi yang disajikan secara daring sesuai dengan } \\
\text { kontrak perkuliahan / RPS }\end{array}$ & 0 & 2 & 4 & 34 & 9 \\
\hline 4. & $\begin{array}{l}\text { Perkuliahan secara daring menambah pemahaman } \\
\text { teori dan keterampilan }\end{array}$ & 4 & 17 & 15 & 13 & 0 \\
\hline 5. & Kemudahan dalam mengirim tugas & 0 & 6 & 5 & 35 & 3 \\
\hline 6. & $\begin{array}{l}\text { Dosen memberikan kesempatan untuk bertanya dan } \\
\text { berdiskusi }\end{array}$ & 0 & 1 & 2 & 27 & 19 \\
\hline 7. & $\begin{array}{l}\text { Dosen memberikan respon terhadap pertanyaan } \\
\text { yang muncul selama perkuliahan secara daring }\end{array}$ & 0 & 1 & 0 & 35 & 13 \\
\hline 8. & $\begin{array}{l}\text { Dosen selalu menemani ketika pembelajaran secara } \\
\text { daring hingga selesai }\end{array}$ & 0 & 1 & 0 & 29 & 19 \\
\hline 9. & $\begin{array}{l}\text { Dosen menjelaskan arah dan tujuan dalam setiap } \\
\text { pembelajaran secara daring }\end{array}$ & 0 & 1 & 3 & 32 & 13 \\
\hline 10. & $\begin{array}{l}\text { Perkuliahan Daring lebih memberi kemudahan } \\
\text { dalam berinteraksi dengan mahasiswa }\end{array}$ & 9 & 18 & 12 & 9 & 1 \\
\hline
\end{tabular}

Keterangan:

STS: sangat tidak setuju, TS: tidak setuju, RR: ragu-ragu, S: setuju, SS: sangat setuju

Selanjutnya hasil tabel diatas dianalisis untuk mengetahui persentase persepsi mahasiswa terhadap setiap butir pernyataan, yang digambarkan pada Gambar 1 berikut. 


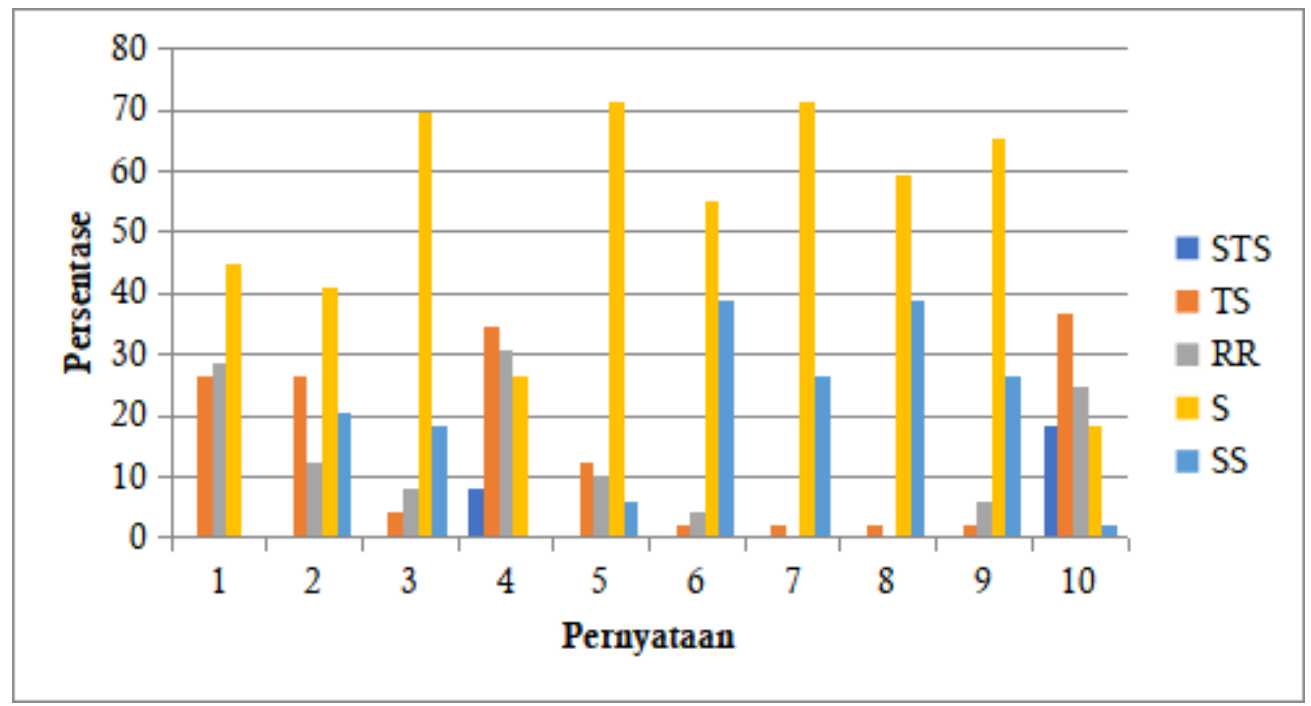

Gambar 1. Grafik Persentase Persepsi Mahasiswa terhadap Perkuliahan Daring pada Masa Pandemi Covid-19.

\section{Pembahasan}

Hasil penelitian yang diperoleh dengan menggunakan angket yang terdiri atas 10 pernyataan dan 5 pilihan jawaban untuk mengetahui kecenderungan persepsi mahasiswa terhadap perkuliahan daring menunjukkan bahwa untuk pernyataan 1 mengenai perkuliahan daring dapat diakses secara mudah, mendapatkan respon sebanyak 44,9\% mahasiswa menyatakan setuju, 28,6\% menjawab ragu-ragu dan 26,5\% menjawab tidak setuju. Dengan demikian dapat dikatakan bahwa mahasiswa cenderung memiliki persepsi jika perkuliahan daring mudah diakses. Adapun yang menjawab tidak setuju karena terbatasnya jaringan internet, kuota atau smartphone yang digunakan tidak memadai. Hasil analisis data pernyataan 2 mengenai perkuliahan daring tepat waktu dan sesuai dengan jadwal, diperoleh sebanyak 40,8\% mahasiswa yang menjawab setuju, sangat setuju sebanyak 20,4\%, 12,3\% menjawab ragu-ragu dan 26,5\% menjawab tidak setuju. Hal ini menunjukkan bahwa mahasiswa cenderung menganggap bahwa perkuliahan daring dapat terlaksana tepat waktu dan sesuai jadwal yang telah ditentukan. Namun, ada beberapa kondisi dimana perkuliahan tidak bisa terlaksana sesuai dengan jadwal yang ada, seperti jaringan tidak memadai ketika listrik padam. Menurut Maulana \& Hamidi (2020), penyebab mahasiswa kesulitan mengakses pembelajaran daring, yaitu: 1) kondisi jaringan yang tidak stabil atau tidak memadai, 2) gadget/perangkat yang tidak kompatibel dengan aplikasi pembelajaran daring, dan 3) kuota internet yang terbatas.

Hasil analisis data pernyataan 3 yaitu materi yang disajikan secara daring sesuai dengan kontrak perkuliahan/RPS, menunjukkan bahwa sebanyak 18,4\% menjawab sangat setuju, 69,4\% mahasiswa menjawab setuju, 8,2\% menjawab ragu-ragu dan 4\% tidak setuju. Hal ini menunjukkan bahwa walaupun pembelajaran dilaksanakan secara daring, Dosen pengampu mata kuliah masih tetap melaksanakan perkuliahan sesuai dengan RPS yang telah disampaikan pada pertemuan pertama. Pernyataan 4 mengenai persepsi mahasiswa terhadap 
perkuliahan secara daring menambah pemahaman teori dan keterampilan mendapat respon sebesar 26,5\% menjawab setuju, 30,6\% menjawab ragu-ragu, 34,7\% menjawab tidak setuju dan $8,2 \%$ yang sangat tidak setuju. Hal ini menunjukkan bahwa dalam pembelajaran daring tidak bisa maksimal seperti halnya perkuliahan secara luring baik dalam pemahaman teori maupun dalam peningkatan keterampilan (praktek). Dalam perkuliahan daring, mahasiswa memperoleh kesulitan untuk memahami materi karena penyampaian materi yang kadang tidak maksimal. Demikian pula dengan praktikum yang tidak bisa dilaksanakan di laboratorium sehingga mahasiswa memiliki keterbatasan baik alat maupun bahan dalam praktikum. Menurut Maulana dan Hamidi (2020), pembelajaran yang dilakukan secara daring sudah baik, namun terkadang ada sulit mahasiswa memahami beberapa hal pada handout yang biasanya bisa dijelaskan melalui tatap muka. Terkhusus pada mata kuliah praktikum, karena butuh waktu yang lebih banyak untuk bisa memahami sendiri. Tidak bisa berdiskusi secara bebas karena secara daring agak terbatas. Selain itu, terkadang gangguan terhadap jaringan yang terjadi karena hal-hal tertentu, seperti salah satunya pemadaman listrik".

Hasil analisis data pernyataan 5 mengenai kemudahan dalam mengirim tugas dalam perkuliahan daring menunjukkan bahwa sebanyak $6,1 \%$ sangat setuju, $71,4 \%$ mahasiswa menjawab setuju, 10,2\% ragu-ragu, dan 12,3\% tidak setuju. Hal ini dapat dikatakan bahwa mahasiswa merasa bahwa dalam perkuliahan daring tugas bisa lebih mudah dikirim karena bisa dilakukan kapan saja dan dimana saja serta tidak membutuhkan biaya untuk printout lagi. Selain itu, pengumpulan tugas yang lewat deadline waktunya tetap bisa dikumpulkan dan diterima karena kadangkala jaringan tidak memadai. Namun meskipun demikian, mahasiswa harus memberikan konfirmasi kepada Dosen terkait tugas yang sudah masuk atau belum. Pernyataan 6 yaitu Dosen memberikan kesempatan untuk bertanya dan berdiskusi diperoleh bahwa $38,8 \%$ sangat setuju, $55,2 \%$ setuju, $4 \%$ ragu-ragu dan $2 \%$ tidak setuju. Hal ini menunjukkan bahwa dalam perkuliahan daring tetap dilaksanakan proses diskusi dan tanya jawab. Proses diskusi dan tanya jawab biasanya dilakukan melalui beberapa platform seperti WhatsApp grup dan Zoom meeting yang diawali dengan presentasi tugas yang telah diberikan kepada mahasiswa.

Pernyataan 7 mengenai Dosen memberikan respon terhadap pertanyaan yang muncul selama perkuliahan secara daring diperoleh respon sebanyak $26,5 \%$ menjawab sangat setuju, $71,5 \%$ setuju dan $2 \%$ tidak setuju. Hal ini menunjukkan bahwa selama proses perkuliahan berlangsung, dosen selalu memberikan kesempatan kepada mahasiswa untuk bertanya. Waktu bertanya diberikan setelah dosen menjelaskan materi. Mahasiswa bisa bertanya jika ada hal-hal yang belum dipahami terkait materi yang telah disampaikan dan didiskusikan. Pertanyaan bisa diajukan secara langsung melalui zoom meeting ataupun WhatsApp grup. Semua mahasiswa 
mendapat kesempatan untuk bertanya dan semua akan diberikan jawaban oleh Dosen ataupun mahasiswa lain yang tahu. Menurut Johanes (2018), peran dosen dalam pembelajaran berpusat pada mahasiswa bergeser dari semula menjadi pengajar (lecturer) menjadi fasilitator. Fasilitator adalah orang yang memberikan fasilitasi. Dalam hal ini adalah memfasilitasi proses pembelajaran mahasiswa. Sebagai fasilitator, dosen adalah penentu atau penyedia sarana yang dapat mengilhami mahasiswa dalam berpikir aktif dan kreatif. Pernyataan 8 mengenai Dosen selalu menemani ketika pembelajaran secara daring hingga selesai mendapatkan respon sebanyak 38,8\% sangat setuju, 59,2\% setuju dan 2\% yang tidak setuju. Hal ini dapat dikatakan bahwa selama proses perkuliahan daring berlangsung, dosen selalu ikut serta baik dalam menyampaikan materi maupun sebagai fasilitator saat proses diskusi.

Pernyataan 9 mengenai Dosen menjelaskan arah dan tujuan dalam setiap pembelajaran secara daring diperoleh respon sebanyak $26,5 \%$ sangat setuju, $65,4 \%$ setuju, $6,1 \%$ ragu-ragu dan $2 \%$ tidak setuju. Hal ini menandakan bahwa sebelum proses perkuliahan berlangsung dosen menyampaikan tujuan pembelajaran diawal perkuliahan dan mengarahkan proses perkuliahan sampai materi selesai. Pernyataan 10 mengenai perkuliahan daring lebih memberi kemudahan dalam berinteraksi dengan mahasiswa memperoleh respon sebesar $2 \%$ sangat setuju, 18,4\% setuju, 24,5\% ragu-ragu, 36,7\% tidak setuju dan 18,4\% sangat tidak setuju. Hal ini menunjukkan bahwa selama proses perkuliahan daring, mahasiswa tidak punya banyak waktu untuk berinteraksi dengan mahasiswa lain sehingga memiliki kesulitan untuk berdiskusi dan berbagi informasi. Menurut Slavin (2011), Vygotsky sangat menekankan pentingnya peranan lingkungan kebudayaan dan interaksi sosial dalam perkembangan sifat-sifat dan tipe-tipe manusia. Menurut Vygotsky siswa sebaiknya belajar melalui interaksi dengan orang dewasa dan teman sebaya yang lebih mampu. Interaksi sosial ini memacu terbentuknya ide baru dan memperkaya perkembangan intelektual siswa.

Hasil penelitian yang diperoleh didukung oleh beberapa penelitian sebelumnya dimana persepsi mahasiswa terhadap kuliah online termasuk kategori baik. Menurut Anhusadar (2020), perkuliahan daring diharapkan dapat membantu mahasiswa dalam di masa pandemi Covid-19, karena perkuliahan yang baik dan benar akan membantu mahasiswa dalam meningkatkan pemahaman dan keilmuan. Banyaknya mahasiswa yang belum mendapatkan jaringan internet yang memadai di daerahnya tetapi tidak mengurangi semangat untuk mengikuti kuliah online. Mahasiswa menggunakan alat elektronik seperti handphone dan laptop dalam mengikuti proses perkuliahan online. Selain itu, menurut Maulana \& Hamidi (2020), persepsi positif mahasiswa terhadap pembelajaran daring dilihat dari aspek belajar mengajar, kapabilitas (kemampuan dosen), serta sarana dan prasarana. Pembelajaran daring masih terkendala oleh akses internet yang masih terbatas khususnya di daerah rural dan kondisi ekonomi mahasiswa yang terbatas 
sehingga tidak memiliki perangkat yang memadai untuk mengakses aplikasi pada pembelajaran daring.

Berdasarkan hasil penelitian yang diperoleh bahwa secara keseluruhan persepsi mahasiswa Pendidikan Biologi Universitas Muhammadiyah Luwuk terhadap pelaksanaan perkuliahan daring adalah baik. Namun ada beberapa hal yang masih perlu menjadi perhatian bagi Dosen baik dalam proses belajar mengajar maupun kapabilitas (kompetensi dosen). Aspek yang masih harus menjadi perhatian Dosen diantaranya masih banyak mahasiswa yang masih mengalami kesulitan dalam mengikuti perkuliahan, perkuliahan daring dianggap kurang menambah pemahaman teori dan keterampilan dan perkuliahan daring belum memberi kemudahan dalam berinteraksi dengan mahasiswa. Oleh karena itu, untuk perbaikan proses perkuliahan selanjutnya bisa dikombinasikan dengan perkuliahan luring, melaksanakan praktikum di laboratorium kampus, dengan demikian tetap tercipta interaksi antar mahasiswa dan memudahkan dalam memahami materi tetapi tetap mematuhi protokol kesehatan

\section{SIMPULAN}

Hasil analisis persepsi mahasiswa Program Studi Pendidikan Biologi terhadap perkuliahan daring pada masa pandemi Covid-19 secara keseluruhan adalah baik. Hal ini diketahui bahwa sebanyak 44,9\% mahasiswa setuju perkuliahan daring dapat diakses secara mudah, 61,2\% mahasiswa setuju perkuliahan daring tepat waktu dan sesuai dengan jadwal, $69,4 \%$ mahasiswa setuju materi yang disajikan secara daring sesuai dengan kontrak perkuliahan/RPS, 42,9\% mahasiswa tidak setuju jika perkuliahan secara daring menambah pemahaman teori dan keterampilan, 77,5\% mahasiswa setuju mendapatkan kemudahan dalam mengirim tugas dalam perkuliahan daring, 94\% mahasiswa setuju bahwa Dosen memberikan kesempatan untuk bertanya dan berdiskusi, 98\% mahasiswa setuju bahwa Dosen memberikan respon terhadap pertanyaan yang muncul selama perkuliahan secara daring, 98\% mahasiswa setuju Dosen selalu menemani ketika pembelajaran secara daring hingga selesai, 91,9\% mahasiswa setuju Dosen menjelaskan arah dan tujuan dalam setiap pembelajaran secara daring, dan $55,1 \%$ mahasiswa tidak setuju jika perkuliahan daring lebih memberi kemudahan dalam berinteraksi dengan mahasiswa lain.

\section{UCAPAN TERIMA KASIH}

Ucapan terima kasih kepada semua pihak yang telah membantu baik saat persiapan dan pelaksanaan penelitian maupun saat penyusunan laporan.

\section{REFERENSI}


Alam, S. \& Jackson, L. (2013). A Case Study: Are Traditional Face-To-Face Lectures Still Relevant When Teaching Engineering Courses? International Journal of Engineering Pedagogy (iJEP), 3 (4), 9-16.

Anhusadar, L. O. (2020). Persepsi Mahasiswa PIAUD terhadap Kuliah Online di Masa Pandemi Covid 19. KINDERGARTEN: Journal of Islamic Early Childhood Education, 3 (1), 44-58. http://dx.doi.org/10.24014/kjiece.v3i1.9609

Carolina, I., Supriyatna, A., \& Puspitasari, D. (2020). Analisa Tingkat Kepuasan Mahasiswa Terhadap Perkuliahan Daring Pada Era Pandemi Covid 19. Prosiding Seminar Nasional Riset dan Information Science (SENARIS), 2, 342-347.

Gikas, J. \& Grant, M. M. (2013). Mobile Computing Devices In Higher Education: Student Perspectives On Learning With Cellphones, Smartphones \& Social Media. Internet And Higher Education, 19, 18-26. https://doi.org/10.1016/j.iheduc.2013.06.002

Johanes. (2018). Peran Dosen Pada Pembelajaran Student Centered Learning. Forum Ilmiah, 15 (1), 133-138,

Maulah, S., Nurul, A. F. \& Ummah, N. R. (2020). Persepsi Mahasiswa Biologi Terhadap Perkuliahan Daring Sebagai Sarana Pembelajaran Selama Pandemi Covid-19. ALVEOLI: Jurnal Pendidikan Biologi, 1 (2), 49-61. https://doi.org/10.35719/alveoli.v1i2.6

Maulana, H. A. \& Hamidi, M. (2020). Persepsi Mahasiswa terhadap Pembelajaran Daring pada Mata Kuliah Praktik di Pendidikan Vokasi. Equilibrium: Jurnal Pendidikan, 8 (2), 224-231. https://doi.org/10.26618/equilibrium.v8i2.3443

Pangondian, R. A., Santosa, P. I., \& Nugroho, E. (2019). Faktor - Faktor Yang Mempengaruhi Kesuksesan Pembelajaran Daring Dalam Revolusi Industri 4.0. Seminar Nasional Teknologi Komputer \& Sains (SAINTEKS), 1(1), 56-60.

Saifuddin, M. F. (2017). E-Learning Dalam Persepsi Mahasiswa. Jurnal Varia Pendidikan, 29 (2), 102-109. https://doi.org/10.23917/varidika.v29i2.5637

Saragih, O., Sebayang F. A. A., Sinaga, A. B. \& Ridlo M. R. (2020). Persepsi Mahasiswa Terhadap Pembelajaran Daring Selama Pandemi Covid-19. Tarbiyah Wa Ta'lim: Jurnal $\begin{array}{llllll}\text { Penelitian Pendidikan } \quad \& \quad & \text { Pembelajaran, } & 7 & \text { (3), } & \text { 178-191. }\end{array}$ https://doi.org/10.21093/twt.v7i3.2624

Slavin, R. E. (2011). Psikologi Pendidikan Teori dan Praktik Edisi Kesembilan Jilid 1. Jakarta: PT Indeks.

Sugihartono., Fathiyah, K. N., Harahap, F., Setiawati, A. S., \& Nurhayati, S. R. (2007). Psikologi Pendidikan. Yogyakarta: UNY Pers.

Suyanto \& Jihad, A. (2013). Menjadi Guru Profesional (Strategi Meningkatkan Kualifikasi dan Kualitas Guru di Era Global). Jakarta: Esensi Erlangga Group. 
Nurlia \& Anggo - Bioedusiana, 6 (1) Juni 2021 